\title{
19. STABLE ISOTOPES AND TERTIARY PALEONTOLOGICAL PALEOCEANOGRAPHY IN THE NORTHEAST ATLANTIC
}

C. Vergnaud Grazzini, Département de Géologie Dynamique, Université Pierre et Marie Curie, 4 Place Jussieu, 75230 Paris, Cedex 05, France

C. Müller, BEICIP, 366 avenue Napoléon Bonaparte, 92502 Rueil Malmaison, France

C. Pierre, R. Létolle, Départment de Géologie Dynamique, Université Pierre et Marie Curie, 4 Place Jussieu, 75230 Paris, Cedex 05, France and

J. P. Peypouquet, Départment de Géologie et Océanographie, Université de Bordeaux I, avenue des Facultés, 33405 Talence, Cedex

\begin{abstract}
Oxygen and carbon isotope analyses of bulk carbonates and forminifer material, as well as micropaleontological studies at North Atlantic DSDP Sites $400,401,403$, and 406 have provided information on the evolution of water masses through Cenozoic time.

The Cenozoic is characterized by a net cooling of the sea water, related to the establishment of a deep cold circulation in the North Atlantic, starting at about $-50 \mathrm{~m}$.y. The establishment of the psychrosphere at -38 m.y. as well as the major ice accumulations on the Antarctic continent at about $-11 \mathrm{~m} . \mathrm{y}$. are not well depicted by the isotopic curves, but the evolution of nannofossil assemblages and of ostracodes may be related to these great events. These isotopic differences may be due to the fact that in that part of the North Atlantic, Antarctic bottom waters may have competed with warmer waters from Tethyian or northern origin; this should explain why Oligocene bottom temperatures remained higher in the Bay of Biscay than elsewhere.

The fluctuations in the nutrients supply that may be deduced from the ${ }^{13} \mathrm{C} /{ }^{12} \mathrm{C}$ ratio variations are also correlated with the influx of cool deep water in the middle Eocene, late middle Miocene, and Pleistocene. Increasing fertility in the middle Eocene time can also be deduced from the occurrence of particular ostracod species and from the sediment composition.
\end{abstract}

\section{INTRODUCTION}

Paleontological studies on coccoliths, foraminifers, and ostracodes combined with isotopic analyses on bulk carbonates and foraminiferal samples from DSDP Sites 400, 401, 403, and 406 (Létolle et al., this volume; Schnitker, this volume; Müller, this volume; Ducasse and Peypouquet, this volume) reveal a general pattern for the climatic evolution of the water masses during Cenozoic time, in the Northeast Atlantic. In this paper we examine and discuss the extent to which this evolution is similar to that reported for Pacific sites at all latitudes, and for South Atlantic sites, and the respects in which they differ. Hole $400 \mathrm{~A}$ and Site 401 (Figure 1) were drilled near the base of the continental margin in the northwest Bay of Biscay, in water depths of 4399 and 2945 meters, respectively; the sites are essentially protected from downslope mass movements. At the present time, North Atlantic Deep Water (temperature $2^{\circ}$ to $2.2^{\circ} \mathrm{C}$, salinity 3.491 to $3.492 \%$ ) occupies Site 400 . North Atlantic Deep Water with a strong mixture of Mediterranean water (temperature $3^{\circ}$ to $3.2^{\circ} \mathrm{C}$ and salinity 3.497 to $3.498 \%$ ) occupies Site 401 (Worthington and Wright, 1970).

Site 403 was drilled on the rifted margin of Rockall Plateau in $\sim 2300$ meters of water. Site 406 was drilled south of the transform fault which controls the southern margin of Rockall Plateau (under $2307 \mathrm{~m}$ of water). The sea floor at these sites is now occupied by North Atlantic water masses from the Iceland-Scotland overflow. At the latitude of Rockall Plateau this water is a well-developed deep current with temperatures less than $2^{\circ} \mathrm{C}$ and salinity less than 3.5 per cent. Surface waters come from the North Atlantic Drift, with summer temperatures around $12^{\circ} \mathrm{C}$ and salinity less than 3.55 per cent.

\section{REVIEW OF THE PROBLEM}

The distribution of microfloras and microfaunas depends on the characteristics of the water masses they inhabit (temperature, salinity, density) as well as on current systems. The evolution of the climatic characteristics of the water masses and that of their movements is, to a large 


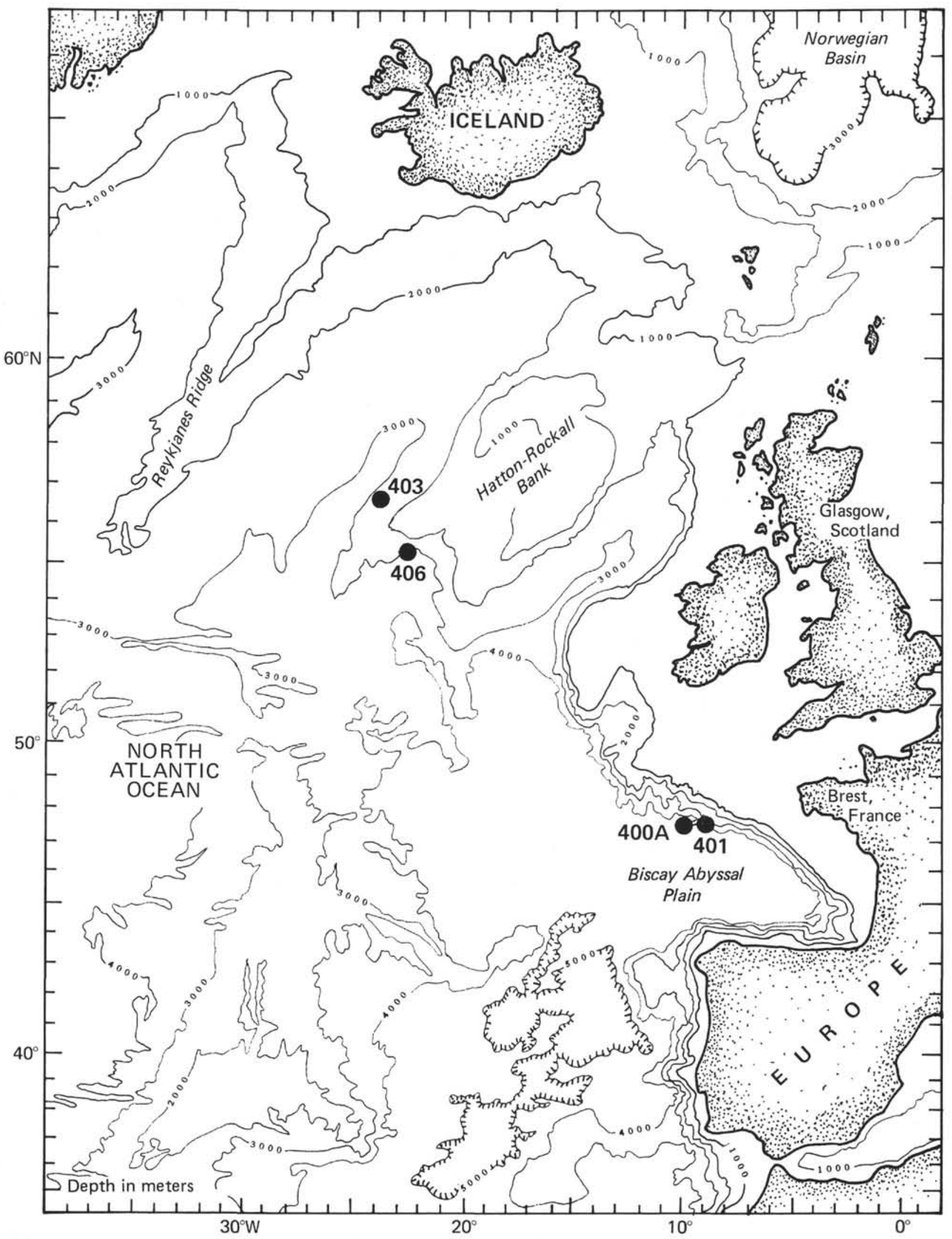

Figure 1. Location of Holes 400A, 401, 403, and 406 in the North Atlantic. 
extent, determined by the quantity of ice stored at the poles and by the degree of opening of the oceans.

The development of polar glaciation that led initially to the formation of Antarctic ice caps, and subsequently to the late Cenozoic ice caps in the Northern Hemisphere, recently has been the focus of much attention. It has been recognized that the Antarctic glaciation has influenced global climate, the sea level and ocean circulation patterns, as well as organic evolution. However, until recently, paleotemperature and paleoceanographic data obtained from oxygen and carbon isotope analyses of foraminifers or calcareous nannofossils in deep-sea sediments older than Pleistocene were few.

Douglas and Savin $(1971,1973,1975)$, and Savin et al. (1975) have presented analyses of Cenozoic planktonic and benthic foraminifers from low and mid latitudes in the Pacific (DSDP Legs 6, 17, and 32) and from South Atlantic mid latitudes (DSDP Leg 3). Saito and Van Donk (1974) have also published isotopic data on Late Cretaceous to early Tertiary material for South Atlantic drillings. The first comprehensive oxygen and carbon isotope record for the past $54 \mathrm{~m} . \mathrm{y}$. was presented by Shackleton and Kennett (1975a), who analyzed sediments drilled at sub-Antarctic latitudes during DSDP Leg 29; they proposed a timing of the accumulation of Antarctic ice through Tertiary time and an estimation of its isotopic effects. A significant drop in isotopic temperature occurred near the late Eocene-early Oligocene boundary, corresponding to a decrease to near freezing in Antarctic surface-water temperatures and to extensive production of sea ice; isotopic temperatures of bottom water at Site 277 at this time $\left(5^{\circ}\right.$ to $\left.6^{\circ} \mathrm{C}\right)$ were well above freezing, however. Kennett and Shackleton (1976) also stated that oxygen isotopic evidence indicates no significant build-up of Antarctic ice at this time.

A second important step in the thermal evolution of the ocean may have taken place in early middle Miocene time (14-15 m.y.B.P.), where an extremely sharp increase in $\delta^{18} \mathrm{O}$ occurs in surface as well as in bottom waters. The magnitude of this isotopic change is similar to that of the change near the Eocene/Oligocene boundary, although it seems difficult to assess what proportions of the isotopic increase is due to temperature changes or to changes of the oxygen isotopic composition of the water caused by accumulation of Antarctic ice (Savin, 1977). Shackleton and Kennett (1975a) interpret benthic foraminiferal isotopic changes between middle Miocene and middle late Miocene time as reflecting mostly changes in the size of the Antarctic ice sheet. For these authors the Antarctic ice cap reached its present size by early late Miocene time. However, Savin et al. (1975) do not feel it is possible to separate the ice effect from the temperature effect during that time interval. According to Shackleton and Kennett (1975a), in the middle late Miocene the Antarctic ice sheet became stabilized. Thus, prior to that time, the oceans were lighter than they are today - the estimated difference being 0.9 per mil and isotopic changes in deep waters would result essentially from temperature changes.

In a recent paper, Margolis et al. (1977) present a summary of oxygen and carbon isotope data for benthic foraminifers, planktonic foraminifers, and nannofossils from different sites and different latitudes in the Pacific and the Atlantic. They also extend the paleotemperature record in the sub-Antarctic back to -80 m.y.B.P. (the Late Cretaceous).

In a still more recent paper, Boersma and Shackleton (1977a) present a Tertiary oxygen and carbon isotopic stratigraphy in the mid latitudes of the South Atlantic (DSDP Site 357).

In each of these paleotemperature records, the general trends are similar. One may recognize: a warming in the Paleocene/early to middle Eocene occurring in surface as well as bottom waters; a first $\delta^{18} \mathrm{O}$ increase towards the Eocene/Oligocene boundary in surface as well as bottom-dwelling organisms; a second $\delta^{18} \mathrm{O}$ increase starting in the late early to middle Miocene, ending in the late Miocene in surface as well as bottom waters; rapid and intense oxygen isotopic changes starting at about 3 m.y.B.P., representing Northern Hemisphere glacial ice accumulation (Shackleton and Kennett, 1975b).

However, differences appear in the precise timing of these events and in the velocity and intensity of the isotopic changes. These differences may be the result of diagenetic dissolution processes, but they may be due also to differences in depth of deposition, sampling intervals, distances to the zone of production of Antarctic bottom waters, or to the existence of topographic obstacles to the northward penetration of the Antarctic Bottom Water $(A A B W)$. Such differences are clear when the sub-Antarctic paleotemperature record from Holes 277-279A-281 (Shackleton and Kennett, 1975a) is compared to the paleotemperature curves obtained for the Tertiary in the South Atlantic Site 357 (Boersma and Shackleton, 1977a). In terms of North Atlantic paleoceanographic evolution, these differences are predicted to be of a complex nature, owing to: the evolution through time, in the southern part of this ocean, of topographical barriers which may have prevented the penetration of Antarctic deep waters; the uncertain timing of the onset of a deep circulation originating from the northern basins (Labrador Sea) which, according to Berggren and Hollister (1974, 1977), could have occurred as early as the early Tertiary but, according to others (Thiede, in press), not before the subsidence of the Iceland-Faeroe Ridge in middle Miocene time; the variations of the regional westward influence of the Tethys; the regional influence of the Pyrenean orogeny during the Eocene; the extension and vicinity of the northern ice cap in the Pleistocene epoch.

\section{THE STUDY AND ITS OBJECTIVES}

Isotopic analyses for oxygen and carbon were performed on carbonate tests of planktonic and benthic foraminifers selected from levels corresponding to time intervals of 2 to 4 m.y. Bulk carbonate was also analyzed. Bulk carbonate is not of common use in paleotemperature studies because its isotopic record may be altered by diagenesis and/or the presence of detrital carbonates. Nevertheless, when it is assured that these two factors do not play a role (by scanning electron micrographs and smear-slide observations), one may assume that the sample consists mainly of biogenic carbonates (coccoliths and foraminifers). From a weighting point of view, coccoliths are predominant. 
Although a biological (non-equilibrium) fractionation due to environmental factors might in some of the cases influence the isotopic composition of coccoliths (Anderson and Cole, 1975), in most cases precipitation occurs near thermodynamic equilibrium with surface ocean water (Margolis et al., 1975). Thus, one may assume that bulk carbonate isotopic compositions reflect temperature and salinity conditions of superficial waters, at least to a first approximation. Their variations should parallel those displayed by planktonic foraminifers.

\section{THE ISOTOPIC RECORD - EFFECTS OF DIAGENESIS AND DISSOLUTION}

The effects of dissolution and diagenesis on the isotopic record are not yet well known; faunal assemblages are modified by selective dissolution of thin-walled forms which are generally shallow-dwelling hence warmer species. In such cases, the mean isotopic composition no longer reflects the original isotopic record and the apparent isotopic temperature may be altered by several degrees Centigrade (Douglas and Savin, 1973; Berger and Killingley, 1977). Diagenetic recrystallization also modifies the isotopic record. The new isotopic ratios ${ }^{18} \mathrm{O} /{ }^{16} \mathrm{O}$ as well as ${ }^{13} \mathrm{C} /{ }^{12} \mathrm{C}$ depend on the temperature and on the corresponding isotope ratios of the water in which recrystallization occurred. In deeply buried sediments, the isotopic composition and relative amounts of pore water, the carbonate permeability and the geothermal gradient determine the new isotopic composition of the carbonates. In most instances ${ }^{18} \mathrm{O} /{ }^{16} \mathrm{O}$ ratios are lowered during recrystallization. Temperatures calculated from isotopic compositions will hence be higher than growth temperatures. In the case, however, of calcite biogenically precipitated in near surface waters (planktonic foraminifers and nannofossils) second diagenetically precipitated $\mathrm{CaCO}_{3}$ may occur in the form of overgrowths. In such case the higher ${ }^{18} \mathrm{O} /{ }^{16} \mathrm{O}$ ratio of the secondary calcite reflects its formation at colder temperatures. Thus, the ${ }^{18} \mathrm{O} /{ }^{16} \mathrm{O}$ ratio will be greater than that of unaltered planktonic material. This seems more frequent for nannofossils (Douglas and Savin, 1975),

Possibly, comparison of data from sites located in the same region might yield information on alteration of the original isotopic signal.

\section{Holes 400A and 401 (Figures 2 and 3)}

Data from relatively short intervals in the lower to middle Eocene section are rather puzzling. In Hole 400A, presently located in deep waters, the oxygen isotopic values on the average are lower $(\sim 1 \%)$ for bulk carbonates and for planktonic foraminifers, than that measured from the same stratigraphic levels at Site 401. For the period corresponding to the late early Eocene-early middle Eocene, however, the oxygen isotopic compositions measured on benthic foraminifers and nannofossils, at both sites, are not substantially different.

Diagenetic processes, involving dissolution as well as recrystallization, may be responsible for change in the original isotopic signal. In Eocene sediments, at Site 401, the $\delta^{18} \mathrm{O}$ of bulk carbonates is, on the average, higher than the $\delta^{18} \mathrm{O}$ of planktonic foraminifers. At both sites, through
Zones $\mathrm{P} 8$ to $\mathrm{P} 10$, the $\delta^{18} \mathrm{O}$ of bulk carbonates is higher than that of benthonic foraminifers. These results remain to be explained, even though, at Hole 400A, decreasing strontium content in sediments older than Miocene indicates diagenetic recrystallization (Reinard and Létolle, this volume).

\section{Site 406}

At this site, from Eocene to the base of the upper Miocene section, the $\delta^{18} \mathrm{O}$ values are systematically lower than in the other sites. The sediments of this interval (lithologic Units 5 to $2 \mathrm{~B}$ ) are characterized by a low $\mathrm{CaCO}_{3}$ content, interpreted as resulting from dissolution (Site Reports, this volume). Whether the low $\delta^{18} \mathrm{O}$ values are the result of diagenetic dissolution or/and recrystallization, or an indication of warmer surface waters in the North Atlantic, remains unclear. It is difficult to retain the latter alternative because one would expect the same warm effect for Site 403, at nearly the same latitude. In contrast, the isotopic effect of recrystallization (even a partial one) at a temperature depending on the geothermal gradient might well explain some of the isotopic differences between the two sites. For instance, upper Miocene sediments of Site 406, buried 500 meters sub-bottom, are at a temperature around $26^{\circ} \mathrm{C}$; total recrystallization at this temperature in water with $\delta^{18} \mathrm{O} \% 0 \sim-1 \%$ leads to carbonate with an oxygen isotopic composition around $-3 \%$.

\section{CLIMATIC CHARACTERISTICS OF THE WATER MASSES IN THE EARLY TERTIARY}

\section{Paleodepths}

Paleogene benthic foraminiferal assemblages of Holes $400 \mathrm{~A}$ and 401 are identified as belonging to the "Velasco-type" of deep water assemblages, defined by Berggren and Aubert (1975). Although it is difficult to assess the precise depth of the water, a comparison with the Paleogene faunas at South Atlantic Sites 14, 19, 20 and North Atlantic Sites 111 and 119 (Schnitker, this volume) indicates that the difference between the paleodepth and the present depth at Hole 400A is insignificant. Evidently any increase of the top to bottom thermal gradient of the waters should be interpreted as resulting from penetration by cold deep waters and not from a deepening of the basin. At Site 403, the Paleogene benthic assemblage as well as the planktonic/benthic ratio ( $41 \%$, Murray, this volume) point to an outer shelf depth (100 to $180 \mathrm{~m})$. During the middle late Eocene the bottom deepened rapidly and the assemblages correspond first, to the upper part of the epibathyal zone $(250 \mathrm{~m})$ and then, in Oligocene time, the depths were about 600 meters.

Site 406 represents even deeper, epibathyal environments of about 1000 meters.

\section{Water Stratification}

Cluster analyses (Figure 2) of the Paleogene data of Holes $400 \mathrm{~A}$ and 401 show that benthic microfaunas at these sites were strongly dissimilar (Schnitker, this volume), suggesting the existence of an oceanic stratification as early as the late Paleogene. A top-to-bottom isotopic gradient averaging $1 \% 00$ (derived from the comparison of planktonic and benthic foraminiferal analyses at Site 401 - Zones P5 


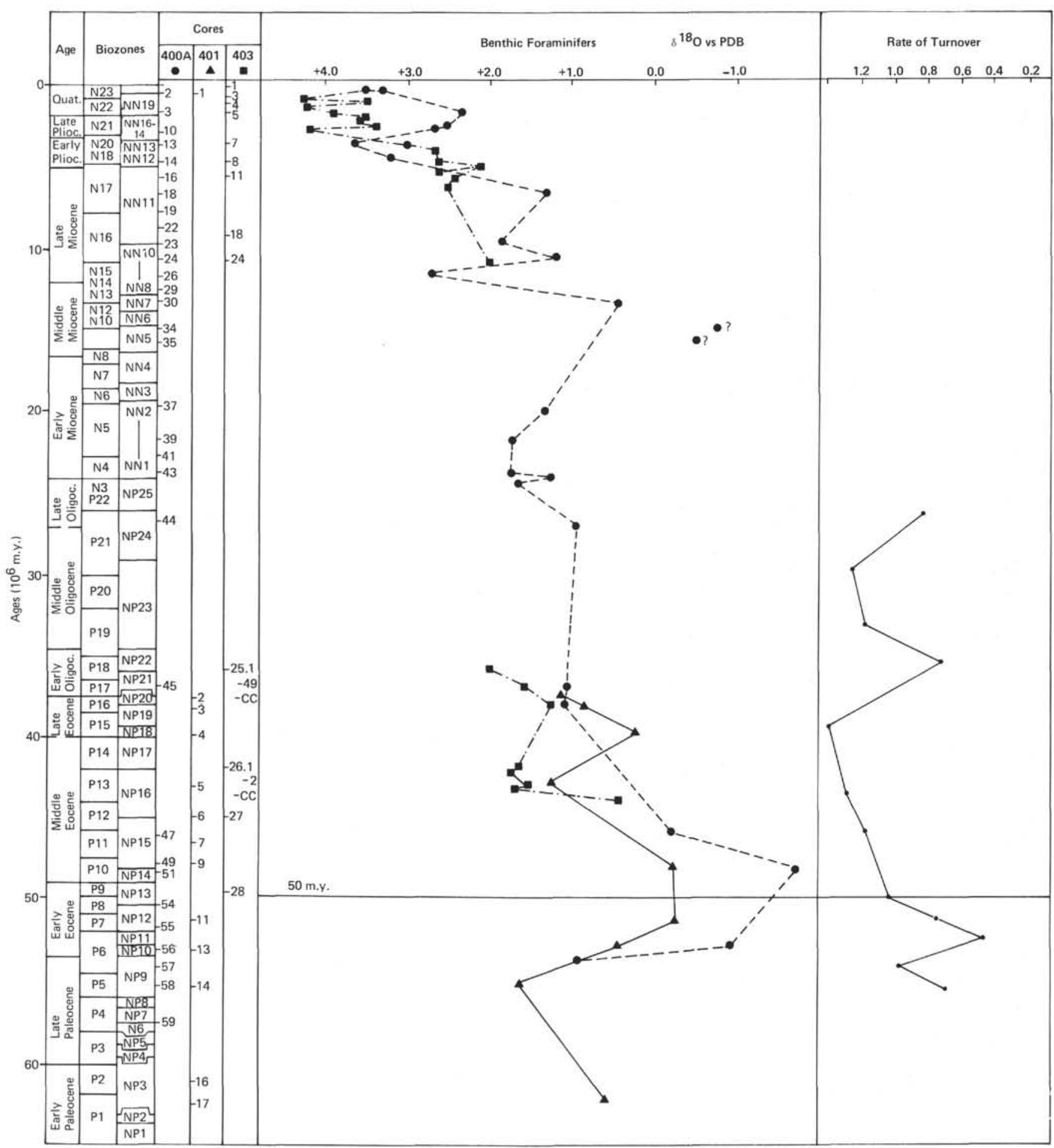

Figure 2. Oxygen isotope curves for benthic foraminifers at Holes 400A, 401, and 403, and rate of faunal turnovers in benthic foraminifers at Hole $400 \mathrm{~A}$ (right) (expressed as the inverse of the time-adjusted coefficient of correlation between adjacent samples).

to P7) indicates an average top-to-bottom temperature gradient of $4^{\circ} \mathrm{C}$, which might be responsible in part for the species stratification.

At Site 403, the few available isotopic data for Core 26 (late Eocene?) indicate a smaller isotopic difference between planktonic and benthic foraminifers (comprised between 0.5 and $0.7 \%$ ) pointing to a top-to-bottom temperature gradient between $2^{\circ}$ and $3^{\circ} \mathrm{C}$. This might result in comparison to the Bay of Biscay, from a shallower depth of Rockall Bank at that time. 


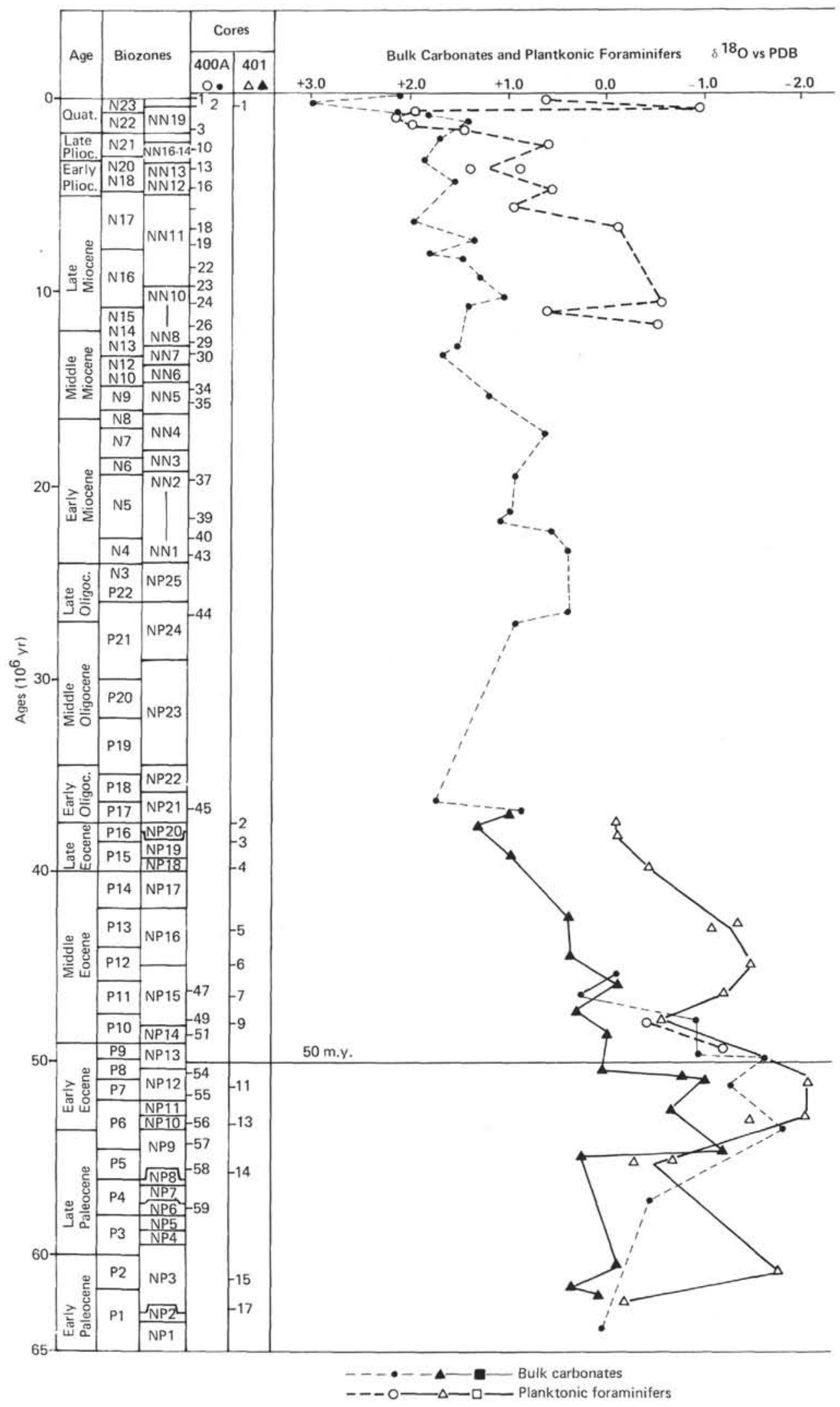

Figure 3. Oxygen isotope curves for planktonic foraminifers and bulk carbonates at Holes $400 \mathrm{~A}, 401$ (on the left), at Site 403 (in the middle), and climatic evolution of nannofossil assemblages (on the right). 


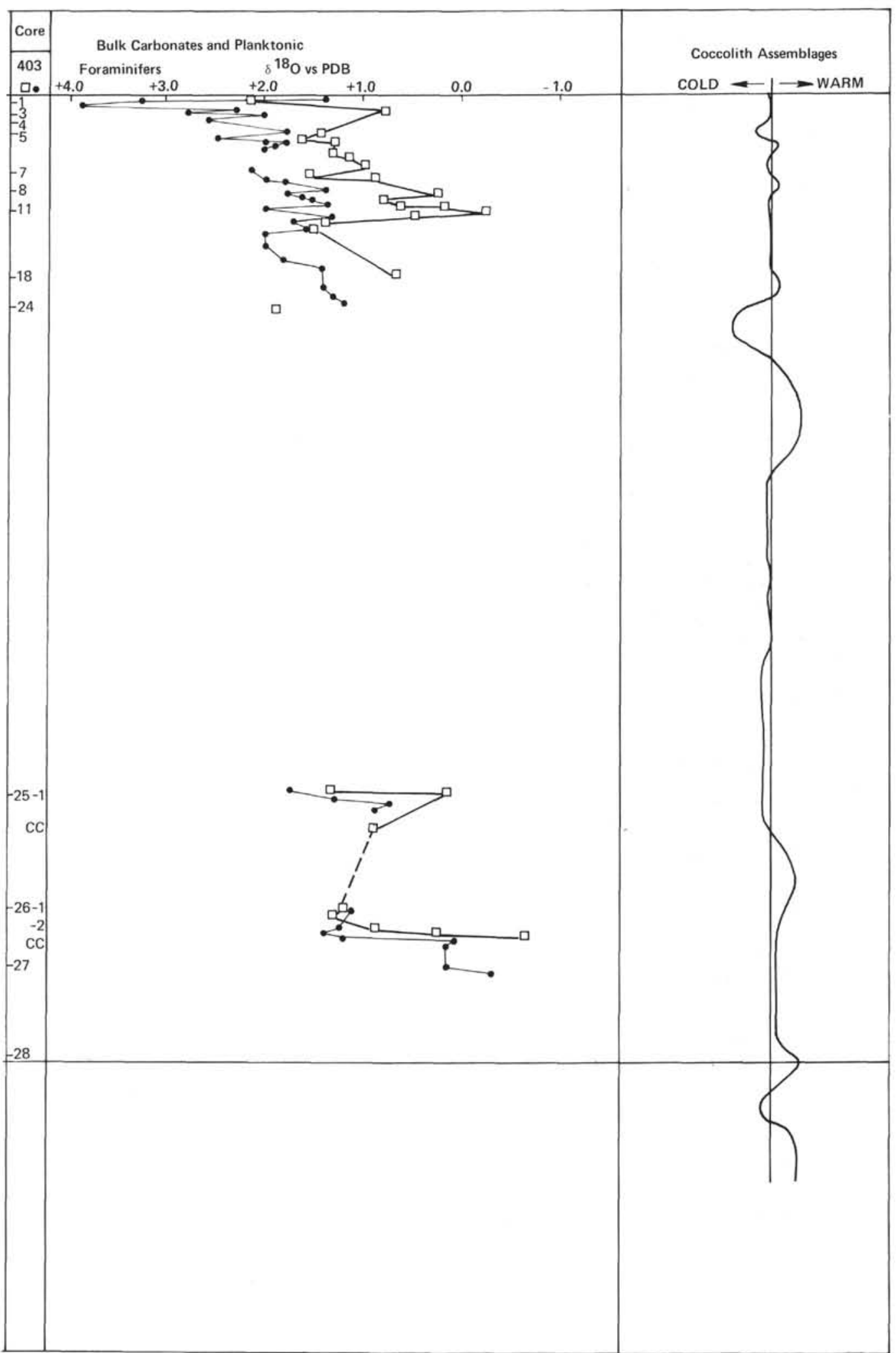

Figure 3. (Continued). 


\section{Temperature Record at the Sea Floor}

For the period before $18 \mathrm{~m} . \mathrm{y}$., the isotopic composition of sea water was $-1.2 \%$ (Shackleton and Kennett, 1975a). Because the samples provided by Schnitker had already been picked, it was not possible to calibrate the species analyzed against uvigerinids; the genera Oridorsalis and Nuttalides were the more frequently analyzed. Some species of the former are in isotopic equilibrium with uvigerinids whereas some species of the latter may differ by $0.35 \%$ from isotopic equilibrium; $\delta^{18} \mathrm{O}$ adjustments were not made and the reported temperature evaluations should be regarded as broad approximations.

In the late Paleogene there was a rise in bottom temperatures culminating through Zones P8 to P10. A peak of faunal turnover, in benthic foraminiferal assemblages, culminating in Zone P6 at the Paleocene/Eocene boundary, indicates conditions of instability in the deep paleoenvironment. Isotopic paleotemperatures calculated at Site 401 reach values around $12.5^{\circ} \mathrm{C}$; this value is similar to that reported by Boersma and Shackleton (1977a) at Site 357. Thus, the warm pool of Atlantic water can be detected at greatly different depths and latitudes and seems to have had a considerable extent at that time. Other reports of warm water conditions then, can be found in the literature (Cheetham and Hakansson, 1972). About the time of Zone P10, bottom temperatures started to decrease (at least in the Bay of Biscay). Isotopic temperatures reached low values (around $7.5^{\circ} \mathrm{C}$ ) in the late Eocene in the Bay of Biscay. At that time on Rockall Bank (Site 403) bottom temperatures, evaluated from mixed benthic species, were around $5^{\circ} \mathrm{C}$. It appears that the North Atlantic was no longer a thermospheric ocean at a time prior to the Oligocene, and that there already existed latitudinal thermal zonations.

This drop in bottom temperatures is reported by Shackleton and Kennett (1975a), Kennett and Shackleton (1976), Savin et al. (1975), Douglas and Savin (1973) for Pacific sediments (of mid and high latitudes - DSDP Sites $167,277)$ and is believed to be Oligocene in age. It most probably corresponds to the same event as that observed in the South Atlantic by Boersma and Shackleton (1977a). However, in the Atlantic the cooling took place in the middle to late Eocene, before Zone P17, and seems to be more progressive. Furthermore, late Eocene isotopic temperatures evaluated for the North Atlantic appear to have been higher than those evaluated for the South Atlantic or the Pacific Ocean. The drop in temperature, which is related mainly to the formation of waters near the freezing point around Antarctica, also suggests some "local" event (on the Atlantic scale) that may have also influenced this evolution, but it cannot presently be assessed whether this local event was the production of cold deep water of northern origin as early as the middle Eocene. Although the Norwegian Sea (formed by the separation of Greenland from Scandinavia) already existed in Eocene time (Harland, 1969; Vine and Hess, 1971), the Iceland-Faeroe Ridge prohibited exchanges between northern basins and the northern part of the Atlantic. According to Berggren and Hollister $(1974,1977)$ the northern flank of the Iceland-Faeroe Ridge had no direct connection with the North Atlantic, and the Norwegian Sea area may have been virtually isolated from the North Atlantic prior to middle Eocene time. The Labrador Basin attained its present size during the late Eocene/early Oligocene. Thus, in the present state of knowledge, it seems difficult to postulate the existence of a deep cold circulation of northern origin. Nevertheless, early middle Eocene time was a time of significant changes in water mass characteristics in the North Atlantic.

These changes are further documented in the evolution of benthic microfaunas, as is evident in the middle Eocene ostracode fauna, where an increase in the number and diversity of species is observed. The most important change occurred in late Eocene time, when species related to Poseidonamicus, Bradleya, Agrenocythere, Bosquetina, and representing the present modern fauna, appeared. This fauna lives today at cold temperatures of less than $8^{\circ}$ to $10^{\circ} \mathrm{C}$ and appeared first in the Rockall Bank area and subsequently in the Bay of Biscay. An important increase in the rate of turnover of benthic foraminiferal assemblages may also indicate important oceanographic changes (Schnitker, this volume). This increase starts near Zone P16 and is maximal near Zone P19.

Later in the Oligocene, bottom temperatures dropped to $3.5^{\circ} \mathrm{C}$ at Rockall Plateau (Site 403, Core 26) near Zone P17, and to 4.5 to $5^{\circ} \mathrm{C}$ in the Bay of Biscay (near Zone P22), suggesting intensification in the rate of production of cold deep water.

In the early Miocene, bottom temperatures appear to have risen although the strong decrease in $\delta^{18} \mathrm{O}$ values observed through Zones $\mathrm{N} 8$ to $\mathrm{N} 12$ (Hole 400A) may very well be an artifact resulting from diagenetic alteration. In the late middle Miocene, temperatures decreased again and the high $\delta^{18} \mathrm{O}$ values observed near Zone $\mathrm{N} 15$ may have resulted from the building up of the Antarctic ice cap. A plausible evaluation of bottom temperatures may be reached only by assuming that the isotopic composition of the sea water was higher than $-1.2 \%$ on the PDB scale.

Then, for the late Neogene, the oscillations observed in the isotopic curves are the effect both of temperature changes and of the growing ice sheets first at the South Pole then at the North Pole. The strong $\delta^{18} \mathrm{O}$ increase which is observed in deep waters only and which culminates at about $-4 \mathrm{~m}$.y. may be the expression of an Antarctic ice sheet much thicker than present. It also correlates with a major regression (Kennett, 1967; Adams et al., 1977) and to a global marine cooling (Kennett and Vella, 1975).

\section{Evolution of Surface Waters}

It is difficult to estimate sea surface temperatures from the oxygen isotopic data obtained from planktonic foraminifers primarily because most species do not produce their calcium carbonate at the ocean surface and also because they may migrate in the water column, recording decreasing temperatures. Further, $\mathrm{CaCO}_{3}$ in both planktonic and benthic species is not always deposited in thermodynamic equilibrium with the surrounding water (Shackleton et al., 1973; Vergnaud Grazzini, 1976; Shackleton and Vincent, 1978). For species older than Quaternary whether the $\delta^{18} \mathrm{O}$ measured corresponds to isotopic equilibrium values or not is conjecture, although the probability is great that it does for Globigerinoides 
species. Most species analyzed in the present study were referred either to the genus Globigerina ( $G$. linaperta in the Bay of Biscay, $G$. bulloides for recent levels of Site 403) or Orbulina. Except in the case of $G$. bulloides, which lives near the surface but is a winter-spring species, it is not possible to determine whether the forms analyzed are actually surface dwellers or not.

Bulk carbonates, as noted before, may be calcite-secreted elsewhere than at the surface and coccoliths are not necessarily in isotopic equilibrium. Thus, all the temperature values we have obtained from the $\delta^{18} \mathrm{O}$ data of planktonic material can only be a first approximation of the true surface temperatures.

\section{Paleocene-Eocene Time}

Near Zone P6 there is a rise in "surface" isotopic temperatures which reach their maximal values between Zones P6 and P8. This maximum thus occurs earlier than the thermal maximum of bottom waters.

If a $\delta^{18} \mathrm{O}$ value $\simeq-1.2 \%$ (on the PDB scale) is used to calculate the temperatures of surface waters (note however that the evaporation-precipitation balance may have affected this parameter), we arrive at surface isotopic temperatures between $16.5^{\circ}$ and $20^{\circ} \mathrm{C}$, which values are not substantially different from those prevailing today at these latitudes in summer.

The abundance of Discoaster multiradiatus in the upper Paleocene-lowermost Eocene of the Bay of Biscay also indicates warmer water temperatures. Discoasters are less frequent at Site 403 which may be due to a latitudinal differentiation, resulting itself from temperature differences, i.e., temperatures appear to have been cooler at Site 403 than in the Bay of Biscay, but the paucity also may be due to these sediments having been deposited in a very shallow environment.

The ${ }^{18} \mathrm{O} /{ }^{16} \mathrm{O}$ ratios start to increase near Zone $\mathrm{P} 8$ at Site 401, and near Zone P9 at Hole 400A. Since diagenesis has much affected Hole $400 \mathrm{~A}$, the lag time may only be artificial. The increase proceeds progressively until the late Eocene time, by which time temperatures have already dropped to values of between $12.5^{\circ} \mathrm{C}$ (as indicated by planktonic foraminifers) and $8^{\circ} \mathrm{C}$ (as indicated by bulk carbonates at Site 401). Although the general trend in Eocene time is the same for different kind of planktonic material and indicates a cooling of the waters, the isotopic curves obtained for planktonic foraminifers and bulk carbonate of the same hole are not exactly parallel. This might simply indicate that bulk carbonate is not an adequate material for this kind of analyses. Diagenetic alteration of nannofossils with calcitic overgrowths (Plate 1) might explain the relatively high $\delta^{18} \mathrm{O}$ values of bulk carbonates.

Nannofossil assemblages indicate episodes of cooling in surface waters interrupted by relatively warmer episodes, but there is no real parallelism between their climatic evolution and isotopic curves. For instance, cooler episodes corresponding to nannoplankton Zone NP 11 and lower part of Zone NP $12(\sim \mathrm{P} 6+\mathrm{P} 7)$, the lower part of NP 14 $(\sim \mathrm{P} 10)$ are difficult to correlate with analogous oscillations in the isotopic paleotemperatures. In contrast, the middle Eocene cooling (NP 15 and NP 16) as well as the upper
Eocene cooling (NP 10-NP 20) agree well with the data concerning ${ }^{18} \mathrm{O} /{ }^{16} \mathrm{O}$ ratios changes. Again a small temperature increase in Zone NP 17 is not significant in the plankton isotopic curve.

This temperature decrease is much more apparent at high latitudes (Rockall Plateau, for instance) where discoasters become rare or are missing in the uppermost Eocene (while they are still common in the Bay of Biscay).

\section{Remarks On The Eocene Cooling}

By the end of the Eocene period, temperatures had dropped through the whole water column, to $5^{\circ} \mathrm{C}$ for bottom waters and to $7.8^{\circ} \mathrm{C}$ for surface waters, in the Bay of Biscay. A similar difference was found by Boersma and Shackleton (1977a) at the South Atlantic Site 357, between thermal evolution of deep waters and surface waters. However, bottom temperatures were cooler in the South Atlantic than in the Bay of Biscay and in Rockall Plateau than in the Bay of Biscay. There, temperatures may have been influenced by the warm waters of the Tethys, or, possibly, the latitudinal thermal differences observed between Rockall Plateau and the Bay of Biscay may well be an indication of the influence of colder water of northern origin, the Labrador Sea for instance.

At the Eocene/Oligocene boundary in the South and North Atlantic, the marked drop in temperatures reported for the Pacific Ocean does not appear. This may be due to the great distance between the location of the sites and the zone of production of AABW, to the influence of warm waters from Tethyan origin, to the influence of waters from northern origin, which were not as cold as $\mathrm{AABW}$, or to an artifact in the sampling.

\section{Oligocene}

Sparse sampling of Oligocene sediments does not allow any precise estimation of the climatic fluctuations of this epoch, but it is evident that all sites yield temperatures that were warmer than today.

Some information can be drawn from the evolution of nannoplankton assemblages. A general characteristic of these assemblages is the lower species diversity compared with those from the middle to late Eocene. This is not restricted to the North Atlantic, but is also known from the Indian Ocean and the Pacific, and indicates a worldwide cooling during Oligocene time.

In the late Oligocene (Zones NP 24 to NP 25) nannofossil ooze was deposited in the Norwegian-Greenland Sea (south and north of the Iceland-Faeroe Ridge and in the Vøring Plateau); this is explained by a northward penetration of Atlantic water masses (Müler, 1976) which coincides with an important transgression in northwest Europe, in the late Oligocene.

In the upper Oligocene section, at Sites 406 and 403, the occurrence of the warm water species Triquetrorhabdulus carinatus may confirm the assumption of warmer water masses penetrating at this time further to the north. The ${ }^{18} \mathrm{O} /{ }^{16} \mathrm{O}$ ratios in bulk carbonates of this epoch indicate a warming in surface waters (Zones N 3 to N 4) while deep waters display an opposite trend. A short warming is also indicated in the South Atlantic at the same time (Boersma and Shackleton, 1977a). 


\section{Miocene/Pliocene}

During the Miocene and Pliocene epochs, the oxygen isotopic composition for planktonic foraminifers and for bulk carbonates continued to increase progressively, the ${ }^{18} \mathrm{O} /{ }^{16} \mathrm{O}$ ratios for bulk carbonates being higher than those for planktonic foraminifers at Hole 400A. Although the ${ }^{18} \mathrm{O} /{ }^{16} \mathrm{O}$ ratio variations reflect the indistinguishable controls of ice-cap growth and sea water temperatures, the nannofossil assemblages give a clue to what the major climatic events of the Miocene period may have been. Nannoplankton assemblages corresponding to Zones $\mathrm{N} 4$ to N 5 (24, 20 m.y.B.P.) suggest a cooling of water temperatures, a trend confirmed by the bulk carbonate isotopic curve near Zone N 5. It may also correlate with a cooling episode reported at Site 357 in the South Atlantic (Boersma and Shackleton, 1977a), and at Site 366 in the Equatorial Atlantic (Vergnaud Grazzini and Rabussier, in press) at a time corresponding to about 22 or $23 \mathrm{~m}$.y. B.P. This date is also when an Antarctic circumpolar current was established, which may have caused an important inflow of colder waters in the Atlantic Ocean (Barker and Burrell, 1977).

Warmer water temperatures are detectable in the nannoplankton assemblages at a time corresponding to Zones N 6 to N 11. Bulk carbonate analyses, however, indicate that the warming was less gradual, with a maximum around 18 m.y. B.P. This warming in early middle Miocene time corresponds to the Hemmoor transgression in North Germany. After this time isotopic paleotemperatures decrease. The relatively cold isotopic peak occurring between Zones N 7 and N 15 (18-11 m.y. B.P.) appears to be less localized in time, at least in the bulk carbonate material, than the strong cooling displayed by nannofossil assemblages (mainly in Zones N 13 to N 15 [13 to $11 \mathrm{~m} . \mathrm{y} . \mathrm{B} . \mathrm{P}]$.$) . Although discoasters are less frequent in$ Zone N 13, they are few to absent in Zones N 14 to N 15 and, as imprecise as the timing of this cooling may be (note, however, that a cold isotopic peak also shows up in the isotopic curves obtained from planktonic as well as benthonic foraminifers), it seems to correspond to the major episode of ice accumulation on the Antarctic continent (Shackleton and Kennett, 1975a).

Nannofossils again reveal warming of a small amplitude in the lower part of Zone N 16 and at the Mio-Pliocene boundary. A similar trend is observed on the isotopic curves of bulk carbonates and planktonic foraminifers (Hole 400A and Site 403). Planktonic foraminifers, however, show that such warming episodes are only "accidents" in a general trend towards cooler conditions and increasing ${ }^{18} \mathrm{O} /{ }^{16} \mathrm{O}$ ratios.

Lower water temperatures prevailed during the late Pliocene; nannofossil assemblages indicate a strong decrease around Zone N 20. This lowering at about 2.5 to 2.7 m.y. B.P. is correlated in the North Atlantic with the first occurrence of ice-rafted material (Berggren, 1972; Muller, this volume). The almost complete extinction of discoasters in the North Atlantic during this period confirms a distinct decrease of water temperature. Although high values of the $\delta^{18} \mathrm{O}$ appear higher in the stratigraphy (around $1 \mathrm{~m} . \mathrm{y}$. B.P.), this may be the result of sparse sampling.

\section{CARBON ISOTOPIC DATA (FIGURE 4)}

The carbon isotopic composition of planktonic and benthic foraminifers reflect the isotopic composition of the dissolved inorganic carbon from which they form their test (Boersma and Shackleton,1977b). It varies vertically in the water column as a consequence of the interplay between photosynthesis at the surface and the oxidation of organic matter at depth. In an open ocean, therefore, with thermohaline circulation, the carbon isotopic compositions of benthic foraminifers should be lighter than that of planktonic foraminifers, and the variations through time of the $\delta^{13} \mathrm{C}$ surface-to-bottom gradient should be a measure of paleofertility. Because it is uncertain that the planktonic species analyzed here actually reflect the $\delta^{13} \mathrm{C}$ content of surface waters, the variations displayed by bulk carbonates, believed to represent calcareous nannofossils, are probably the better yardstick.

From Figure 4 some general features, which also appear in the ${ }^{13} \mathrm{C}$ curves published for Pacific sites (Margolis et al., 1977) or for South Atlantic Site 357 (Boersma and Shackleton, 1977a) are noteworthy: the heavier ${ }^{13} \mathrm{C}$ contents of the Paleocene and middle Miocene (14, 16 m.y.B.P.) faunas; the lighter ${ }^{13} \mathrm{C}$ contents in surface waters starting at about 6 to $8 \mathrm{~m}$.y.B.P. (late Miocene to present). These isotopic events most probably reflect worldwide events (Boersma and Shackleton, 1977b).

Minor "accidents" are well depicted in the Atlantic curves only. Between 46 and $56 \mathrm{~m}$.y.B.P. the $\delta^{13} \mathrm{C}$ becomes lighter for surface as well as for deep biogenic carbonates. This decrease may be related to an increase in surface productivity. At the same time, the surface-to-bottom isotopic gradient is relatively higher than later $(\sim 3 \%)$. In middle Eocene time, ostracode assemblages indicate an increase in nutrients and, thus, in productivity. Sedimentological studies (Auffret and Pastouret, this volume) also point to an increase in surface productivity, from late Paleogene to middle Eocene time in the Bay of Biscay. This is approximately the time of the Pyrenean Orogeny.

The fact that the lighter ${ }^{13} \mathrm{C}$ contents are to be found in a period starting at about $8 \mathrm{~m} . y$. B.P. may be related to the influx of cold waters, rich in nutrients, from northern and southern origins, due to the growth of polar ice caps. This is also the time of the Alpine Orogeny.

However, in the interval between the early Tertiary and the Pleistocene, the overall trend observed in the variation of ${ }^{13} \mathrm{C}$ contents is that of a lightening. This may indicate a global increase in productivity resulting from nutrients supply, related in turn to the establishment of cold deep circulations and to the concomitant orogenic events.

\section{CONCLUSIONS}

Good correlations between paleontological and isotopic events permit reconstruction of part of the paleoceanographic evolution of the Northeast Atlantic during the Tertiary period.

Cenozoic time was characterized by a net cooling of the sea water, which began in middle Eocene time and culminated in the Pleistocene glaciations. Climatic and hydrologic changes, depicted by the isotopic evolution of 


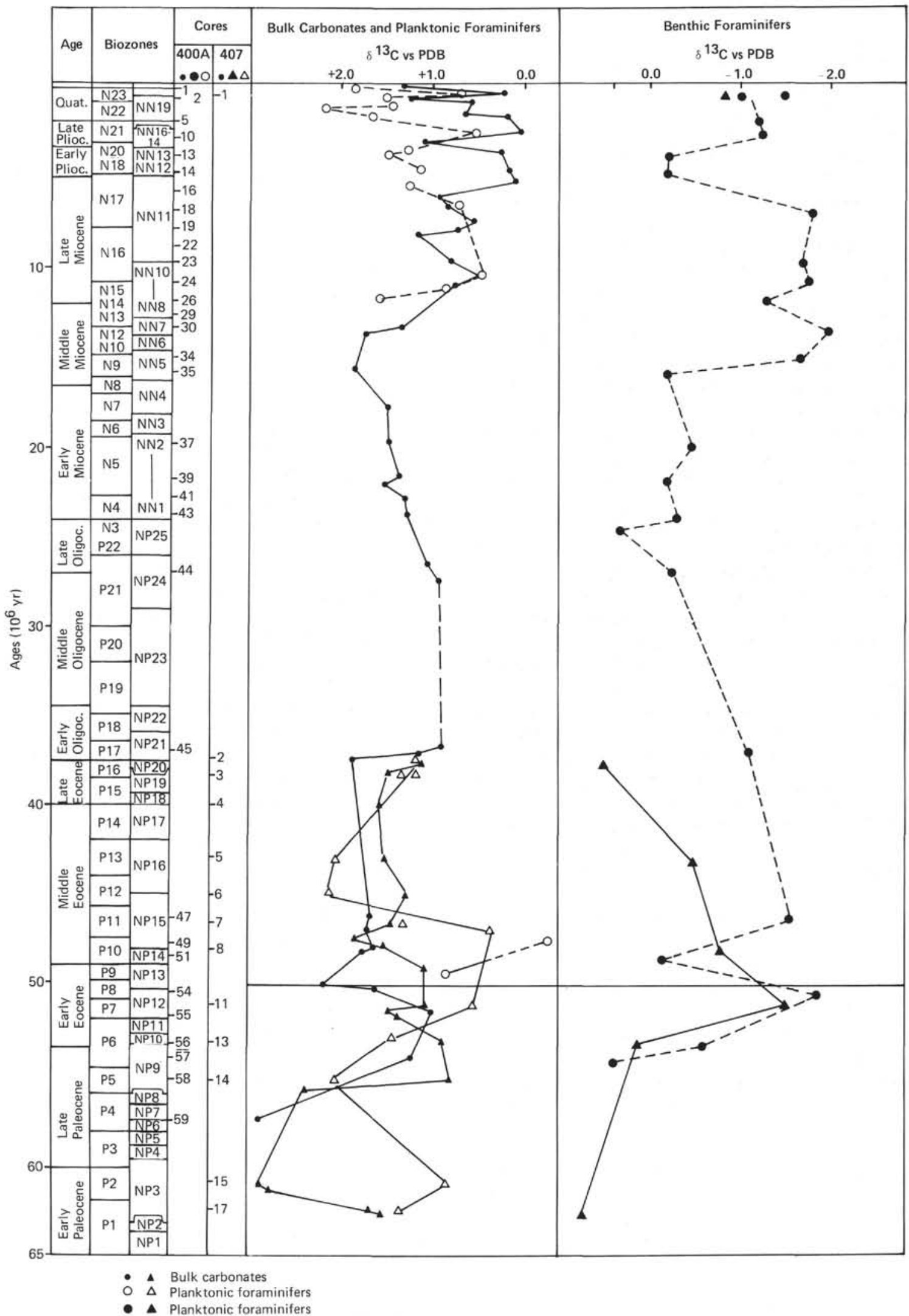

Figure 4. Carbon isotope curves for bulk carbonates and planktonic foraminifers (on the left) and benthic foraminifers (on the right) at Holes $400 \mathrm{~A}$ and 401. 
biogenic carbonates, induced major faunal variations that are reflected in the evolution of the microfauna. The following observations are pertinent:

1) About middle Eocene time, surface and bottom temperatures started to decrease, indicating establishment of a cold deep circulation. Higher than elsewhere at this time, bottom temperatures in the North Atlantic suggest warmer influences from Tethyan or northern origin. Latitudinal thermal zonation existed as early as the Eocene, as indicated by cooler isotopic temperatures, cooler nannofossil assemblages in the northern Sites 403 and 406. In early and middle Eocene time an increase in productivity is depicted by low ${ }^{13} \mathrm{C}$ contents in biogenic carbonates, a high surface-to-bottom $\delta^{13} \mathrm{C}$ gradient, and is corroborated by the ostracode species of the genus Parakrite, and the occurrence of abundant siliceous microfossils. The nutrients necessary for the productivity increase may have been supplied either by the influx of cold deep waters or through terrigenous sources related to the Pyrenean Orogeny.

2) Although isotopic paleotemperatures do not appear to have lowered abruptly at the Eocene/Oligocene boundary, Oligocene temperatures were cooler than Eocene ones and bottom temperatures were less than $8^{\circ} \mathrm{C}$. At this time cold water fauna of ostracodes appeared, corresponding to the " psychrospheric assemblages.", Thus, at that time, a cold deep circulation was well established.

3) During the Miocene and Pliocene time, isotopic paleotemperatures continue to decrease, with occasional warmer episodes in surface waters at the Oligocene/Miocene boundary and between 14 to $18 \mathrm{~m} . \mathrm{y}$., and 8 to $10 \mathrm{~m} . \mathrm{y} . \mathrm{B} . \mathrm{P}$. Although that part of the Atlantic, the isotopic effect of ice accumulating onthe Antarctic continent may have been superimposed with the isotopic curves. The sudden change in nannofossil assemblages at about 11 m.y.B.P. implies that factors other than temperatures may have influenced the microfauna assemblages.

A sharp temperature decrease indicated by nannofossil assemblages in the uppermost part of Zone NN 16 (around zone N 21) between 2.5 and 2.7 m.y.B.P. may correspond to the first appearance of ice-rafted debris in the Northern Hemisphere.

\section{ACKNOWLEDGMENTS}

The authors would like to thank Dr. D. Schnitker for countless hours spent for picking foraminifers for isotopic analyses. We also thank DSDP for providing bulk carbonate samples. Thanks are extended to A. Filly and M. Dudouyt for laboratory assistance. We are grateful to L. Montadert, G. Auffret, J. Thiede, and G. Boillot for several fruitful discussions. This research has been partially funded by CNRS-ATP IPOD and CNEXO.

\section{REFERENCES}

Adams, C.G., Benson, R.H., Kidd, R.B., Ryan, W.B.F., and Wright, R.C., 1977. The Messinian salinity crisis and evidence of late Miocene eustatic changes in the world ocean, Nature, v. 269 , p. $383-386$.

Anderson, T.F., and Cole, S.A., 1975. The stable isotope geochemistry of marine coccoliths: a preliminary comparison with planktonic foraminifers, J.Foram. Res., v. 5, p. 188-192.

Barker, P.F., and Burrell, J., 1977. The opening of Drake Passage, Marine Geology, v. 25, p. 15-34.
Berggren, W.A., 1972. Late Pliocene-Pleistocene glaciation. In Laughton, A.S., Berggren, W.A., et al., Initial Reports of the Deep Sea Drilling Project, v. 12: Washington (U.S. Government Printing Office), p. 953-963.

Berggren, W.A., and Aubert, J., 1975. Paleocene benthonic foraminiferal biostratigraphy, paleobiogeography and paleoecology of Atlantic-Tethyan regions: Midway-type fauna, Paleogeogr., Paleoclimatol., Paleoecol., v. 18, p. 72-192.

Berggren, W.A., and Hollister, C.D., 1974. Paleogeography, paleobiogeography and the history of circulation in the Atlantic Ocean. In Hay, W.W. (Ed.), Studies in Paleo-oceanography, Soc. Economic Paleontologists and Mineralogists, Spec. Publ. 20, p. 126-186.

, 1977. Plate tectonics and paleocirculation-commotion in the ocean, Tectonophysics, v. 38, p. 11-48.

Berger, W.H., and Killingley, J.S., 1977. Glacial holocene transition in deep sea carbonates: selective dissolution and the stable isotope signal, Science, v. 197, p. 563-566.

Boersma, A., and Shackleton, N., 1977a. Tertiary oxygen and carbon isotope stratigraphy, Site 357 (mid latitude South Atlantic), In Supko, P.R., Perch-Nielsen, K., et al., Initial Reports of the Deep Sea Drilling Project, v. 39: Washington (U.S. Government Printing Office), p. 911-924.

,1977b. Oxygen and carbon isotope record through the Oligocene, DSDP Site 366, Equatorial Atlantic. In Lancelot, Y., Seibold, E., et al., Initial Reports of the Deep Sea Drilling Project, v. 41: Washington (U.S. Government Printing Office), p. 957-962.

Cheetham, A.H., and Hakansson, E., 1972. Preliminary report on Bryozoa (Site 117). In Laughton, A.S., Berggren, W.A., et al., Initial Reports of the Deep Sea Drilling Project, v. 12: Washington (U.S. Government Printing Office), p. 432-441.

Douglas, R.G., and Savin, S.M., 1971. Isotopic analyses of planktonic foraminifers from the Cenozoic of the northwest Pacific, Leg 6. In Fischer, A.G., Heezen, B.C., et al., Initial Reports of the Deep Sea Drilling Project, v. 6: Washington (U.S. Government Printing Office), p. 1123-1127.

, 1973. Oxygen and carbon isotope analyses of Cretaceous and Tertiary foraminifera from the Central North Pacific. In Winterer, E.L., Ewing, J.I., et al., Initial Reports of the Deep Sea Drilling Project, v. 17: Washington (U.S. Government Printing Office), p. 591-605.

1975. Oxygen and carbon isotope analyses of Tertiary and Cretaceous microfossils from Shatsky rise and other sites in the North Pacific Ocean. In Larson, R.L., Moberly, R., et al., Initial Reports of the Deep Sea Drilling Project, v. 32: Washington (U.S. Government Printing Office), p. 509-520.

Harland, W.B., 1969. Contribution of Spitsbergen to understanding of tectonic evolution of North Atlantic region, Am. Assoc. Petrol. Geol., Mem. 12, p. 817-852.

Kennett, J.P., 1967. Recognition and correlation of the Kapitean Stage (upper Miocene), New Zealand, New Zealand J. Geol. Geophys., v. 10, p. 1051-1063.

Kennett, J.P., and Shackleton, N.J., 1976. Oxygen isotopic evidence for the development of the psychrosphere $38 \mathrm{Myr}$ ago, Nature, v. 260, p. 513-515.

Kennett, J.P., and Vella, P., 1975. Late Cenozoic planktonic foraminifera and paleoceanography at DSDP Site 284 in the cool subtropical South Pacific. In Kennett, J.P., Houtz, R.E., et al., Initial Reports of the Deep Sea Drilling Project, v. 29: Washington (U.S. Government Printing Office), p. 16.

Margolis, S.V., Kroopnick, P.M., Goodney, D.E., Dudley, W.C., and Mahoney, M.E., 1975. Oxygen and carbon isotopes from calcareous nannofossils as paleo-oceanographic indicators, Science, v. 189, p. 555-557.

Margolis, S.V., Kroopnick, P.M., and Goodney, D.E., 1977. Cenozoic and late Mesozoic paleo-oceanographic and 
paleoglacial history recorded in circum-Antarctic deep-sea sediments, Marine Geology, v. 25, p. 131-147.

Müller, C., 1976. Tertiary and Quaternary calcareous nannoplankton in the Norwegian-Greenland Sea, DSDP, Leg 38. In Talwani, M., Udinstev, G., et al., Initial Reports of the Deep Sea Drilling Project, v. 38: Washington (U.S. Government Printing Office), p. 823-841.

Saito, T., and Van Donk, J., 1974. Oxygen and carbon isotope measurements of late Cretaceous and early Tertiary Foraminifera, Micropaleontology, v. 20, p. 152-177.

Savin, S.M., 1977. The history of the earth's surface temperature during the past 100 Million years, Ann. Rev. Earth Planet. Sci., v. 5, p. 319-355.

Savin, S.M., Douglas, R.G., and Stehli, F.G., 1975. Tertiary marine paleotemperatures, Geol. Soc. Am. Bull., v. 86, p. $1499-1510$.

Shackleton, N.J., Wiseman, J.D.H., and Buckley, H.A., 1973. Non-equilibrium isotopic fractionation between sea water and planktonic foraminiferal tests, Nature. v. 242, p. 177-179.

Shackleton, N.J., and Kennett, J.P., 1975a. Late Cenozoic oxygen and carbon isotopic changes at DSDP Site 284: implications for the glacial history of the northern hemisphere and Antarctica. In Kennett, J.P., Houtz, R.E., et al., Initial Reports of the Deep Sea Drilling Project, v. 29: Washington (U.S. Government Printing Office), p. 801-807.

, 1975b. Paleotemperature history of the Cenozoic and the initiation of Antarctic glaciation: oxygen and carbon isotope analyses in DSDP sites 277, 279 and 281. In Kennett, J.P., Houtz, R.E., et al., Initial Reports of the Deep Sea Drilling Project, v. 29: Washington (U.S. Government Printing Office), p. 743-755.

Shackleton, N.J., and Vincent, E., 1978. Oxygen and carbon isotope studies in recent Foraminifera from the Mozambique Channel region, Marine Micropaleontology, v. 3, p. 1-13.

Thiede, J., in press. Palaeo-oceanography, margin stratigraphy and palaeophysiography of the Tertiary North Atlantic and Norwegian-Greenland seas, Nature, London.

Vergnaud Grazzini, C., 1976. Non-equilibrium isotopic compositions of shells of planktonic Foraminifera in the Mediterranean sea, Palaeogeogr., Palaeoclimatol., Palaeocol., v. 20, p. 263-276.

Vergnaud Grazzini, C., and Rabussier, D., in press. Oxygen and carbon isotopic changes through the Miocene. Site 366 (Equatorial Atlantic). (Abstract in the "Tenth International Congress on Sedimentology,' Jerusalem, IAS, 1978).

Vine, F.J., and Hess, H.H., 1971. Sea floor spreading. In Maxwell, A.E. (Ed.), The Sea.: New York (Interscience), v. 4 , p. $587-622$.

Worthington, L.W., and Wright, W.R., 1970. North Atlantic Ocean atlas of potential temperature and salinity in the deep water, including temperature, salinity and oxygen profiles from the Erika Dan cruise of 1962, Woods Hole Oceanographic Institution Atlas, Series II, p. 24 
PLATE 1

Scanning electron micrographs showing preservation of calcareous nannofossils, Sample 400A, 29-1, $16 \mathrm{~cm}$

Figure 1 Coccoliths, proximal shield, partly dissolved with signs of overgrowths, some fragments of coccoliths. $30,000 \times$.

Figures 2,3 Coccosphere overgrown. Some of the originally lath-shaped elements are blocky due to accretion of secondary calcite; respectively, $9,000 \times$ and $22,000 \times$.

Figure 4 Detail of the Coccosphere, showing growth of calcite crystalsd. $30,000 \times$.

Figure $5 \quad$ Coccolithus pelagicus, Sphenolithus abies with signs of overgrowth and dissolution. Fragments of Coccoliths. $12,000 \times$

Figure 6 Sphenolithus abies has secreted secondary calcite, with signs of dissolution along the sutures. $30,000 \times$. 
PLATE 1

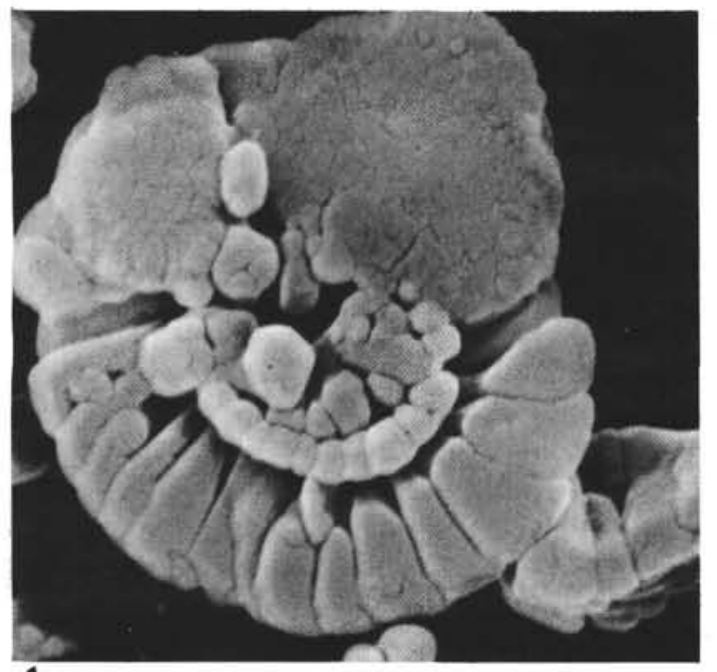

1
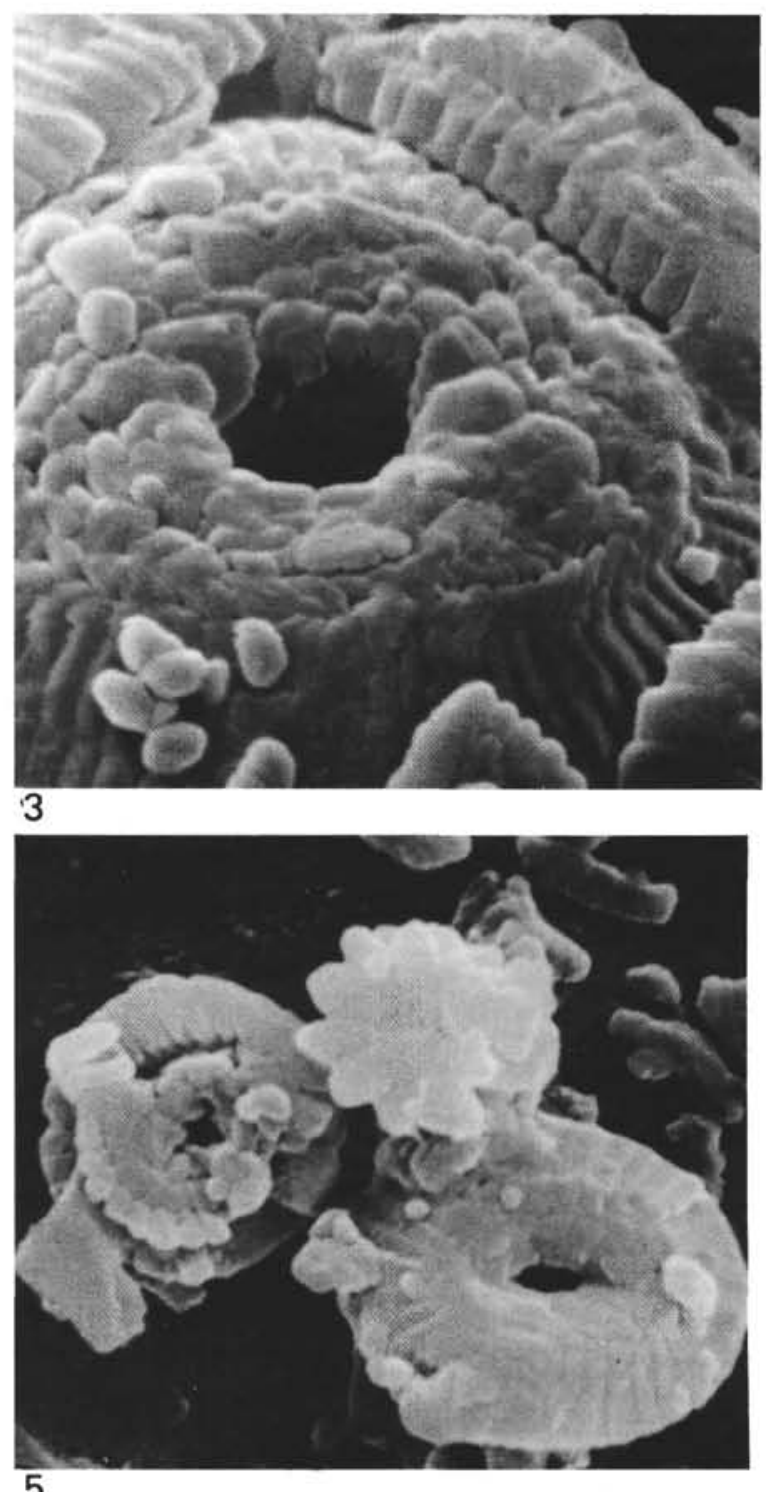

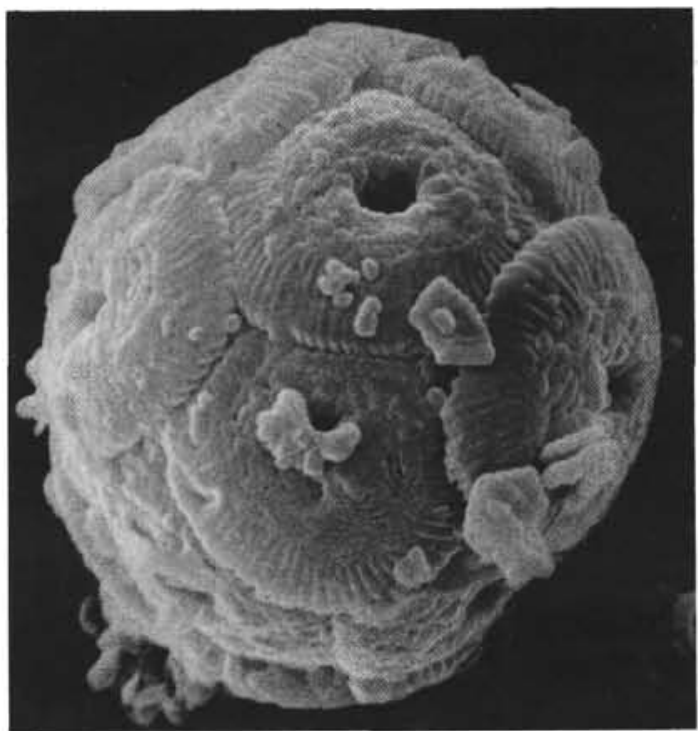

2
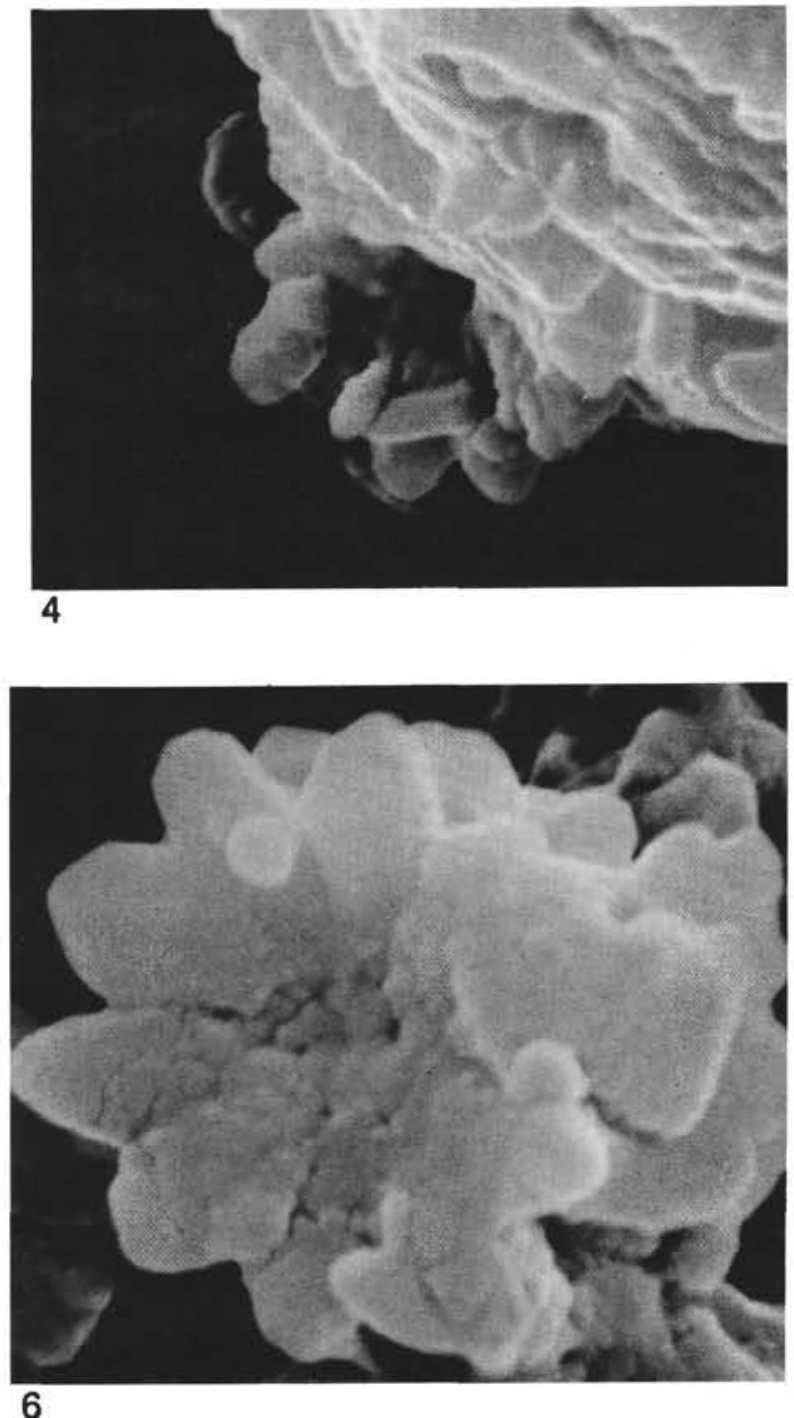


\section{PLATE 2}

Scanning electron micrographs showing preservation of Tertiary calcareous nannofossils, Sample 401, 9-3, $65 \mathrm{~cm}$

Figure 1,3,5 Discoasters showing considerably thickened rays due to accretion of secondary calcite, with signs of dissolution.

1. Discoaster saipanensis, $20,000 \times$.

3. Discoaster sp., $22,000 \times$.

5. Discoaster barbadiensis, $15,000 \times$.

Figure 2 Coccolith, distal shield, central area strongly dissolved with signs of overgrowth, $21,000 \times$.

Figure 4 Coccolith, proximal shield, showing signs of strong dissolution, $30,000 \times$.

Figure 6 Coccoliths and Discoasters showing dissolution and overgrowth features, with some fragments of Coccoliths, $4,000 \times$. 
PLATE 2
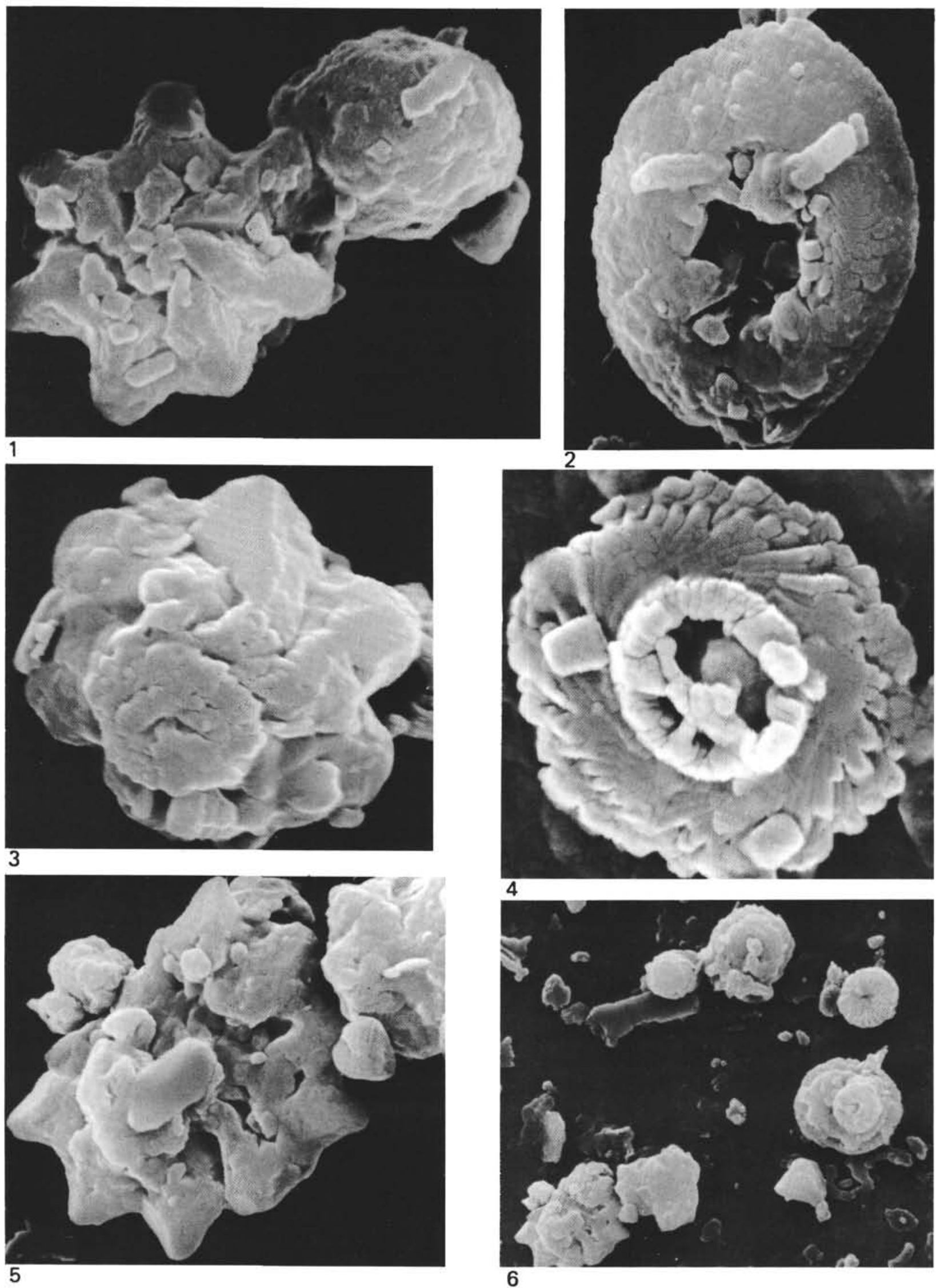